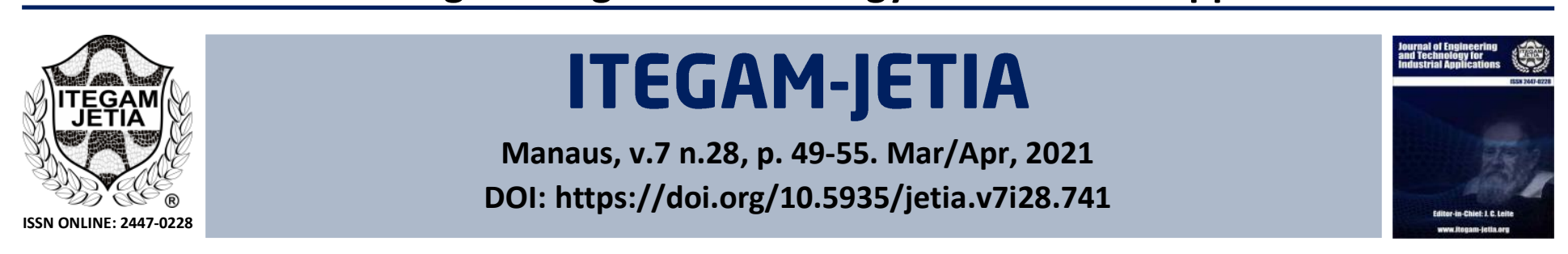

\title{
THE ANALYSIS OF THE RECENT PERIODS OF OAT MARKET IN TURKEY
}

\author{
Zeliha Şahin"1, Mustafa Hakkı Aydoğdu², Gönül Sevinç*3 and Nihat Küçüik ${ }^{4}$ \\ 1, 2, 3 Department of Agricultural Economics, Faculty of Agriculture, Harran University. Sanlıurfa, Turkey. \\ ${ }^{4}$ Department of Economic Policy, Faculty of Economics and Administrative Sciences, Harran University. Sanlurfa, Turkey.

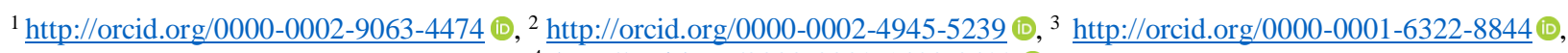 \\ 4 http://orcid.org/0000-0002-1483-0422 (i)
}

Email: zelihasahiin@gmail.com, mhaydogdu@hotmail.com, *gsevinc@harran.edu.tr, nihatk@harran.edu.tr

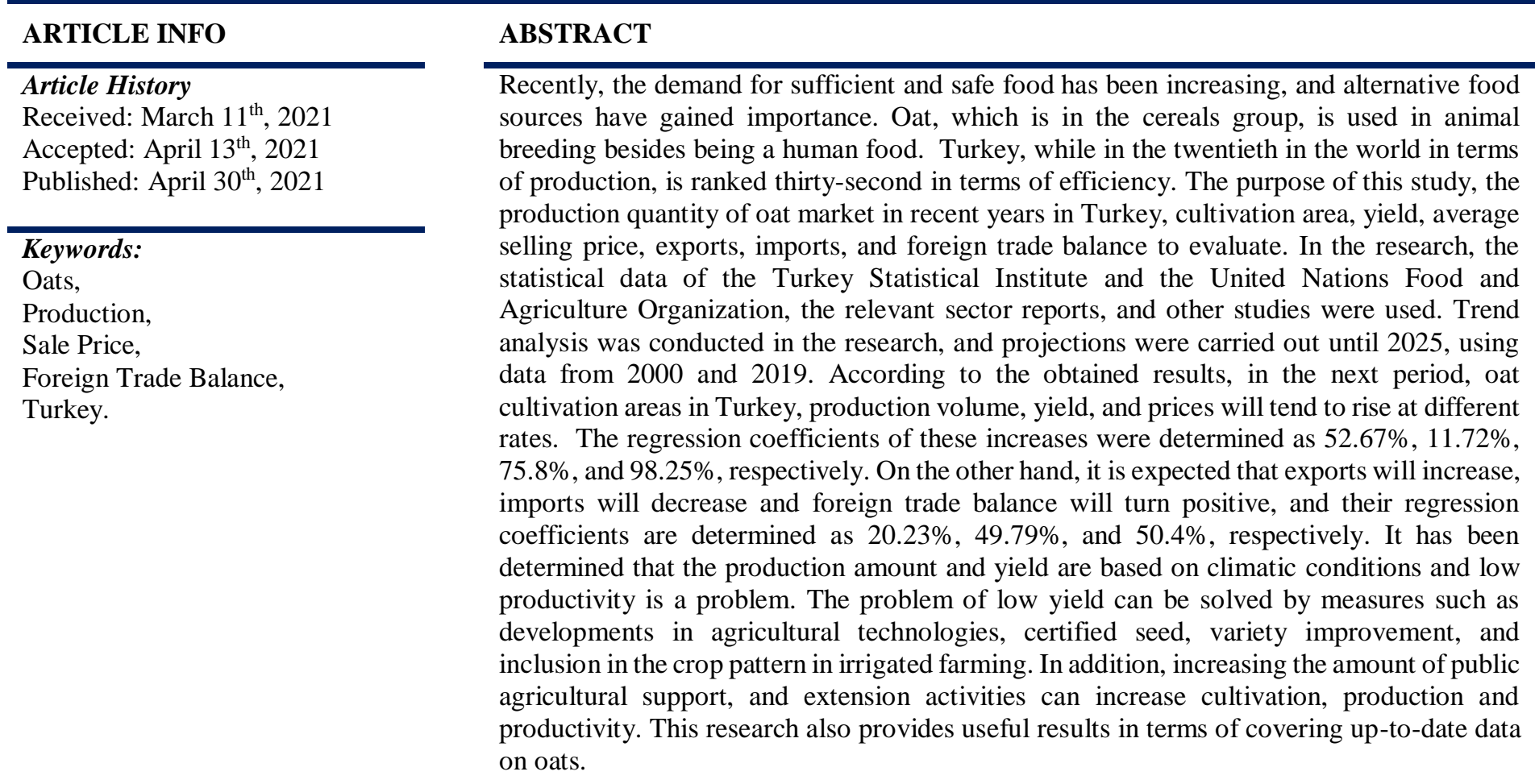

Copyright (C2016 by authors and Galileo Institute of Technology and Education of the Amazon (ITEGAM). This work is licensed under the Creative Commons Attribution International License (CC BY 4.0).

\section{INTRODUCTION}

Globally, more frequent climate changes and droughts [1-4] have started to raise concerns in terms of sustainable agricultural production [5], consequently food security [6], consumption of safe, healthy and nutritious food [7],[8]. The increasing world population brings along the problem of sufficient, quality, and balanced nutrition [9],[10]. These concerns direct people to alternative food sources. Due to the carbohydrates and proteins, it contains, oats have become one of the foods recommended for human health and included in consumption [8].
Oat (Avena sativa) is from the Grammineae family and is one of the annual cool climate cereals [11]. Oat, which is a newer cultivated plant compared to wheat and barley, was cultivated in the 1st-century a.d. and spread to Europe in the 5th century and from there to the whole world. Especially in the Seljuk and Ottoman Periods, oats were also used as bread cereals during the scarcity years [12]. Oats, which can be used as both animal and human food, have become more important in terms of health in human nutrition today [13], [14]. In addition to being used in baby food, oats are consumed as breakfast with oatmeal and rolled oats, and it is also common to use oat grains in biscuits, soups, sausages, gravy, and bread-making [11],[13],[15]. Being rich in protein, fat, 
vitamins, phosphorus, iron and calcium increases its consumption [11], [13], [16]. Oat is an important grain for human health in terms of reducing cholesterol and fat in the blood, preventing anemia, and reducing the risk of coronary heart disease in diabetic diets [8], [11]. On the other hand, oats have an important place in hay and silage feed mixes in livestock [17], [18]. There is also the use of oats as a green fertilizer. The substance of "avenin" in oat grain provides important benefits in strengthening and developing animal muscles and increasing milk yield [15].

Oat is the cool climate cereals in terms of cultivation area on this group ranks 4th in Turkey [19]. In addition to being a cereal plant with less soil selectivity, oats can be grown for low yield and animal husbandry purposes even in barren soils with low soil moisture. On the other hand, oats are one of the plants that can be planted in turning swampy areas into agricultural land [15], [16], [20].

In Turkey, in oat production within the scope of agricultural support payments in 2020, $19 \mathrm{TL} / \mathrm{da}$ diesel, $8 \mathrm{TL} / \mathrm{da}$ the fertilizer subsidy, $6 \mathrm{TL} / \mathrm{da}$ domestic certified seed usage support, and 0.08 $\mathrm{TL} / \mathrm{da}$ international certified seed usage support are given support production overseas certified seed are given. In addition, 40 (TL/Sample) for Soil Analysis Support, 10 TL for solid organicorgan mineral fertilizer support, $35 \mathrm{TL} / \mathrm{da}$ for agricultural extension and consultancy, $60 \mathrm{TL} / \mathrm{da}$ for one-year forage crop support, and $40 \mathrm{TL} /$ da for forage plants planted in dry conditions are given [21].

According to FAO data, it was determined that oat production is widespread in the world, and oat farming was carried out in 73 countries in 2019. The top 20 countries in the world in 2019 oat cultivation areas are given in Figure 1.

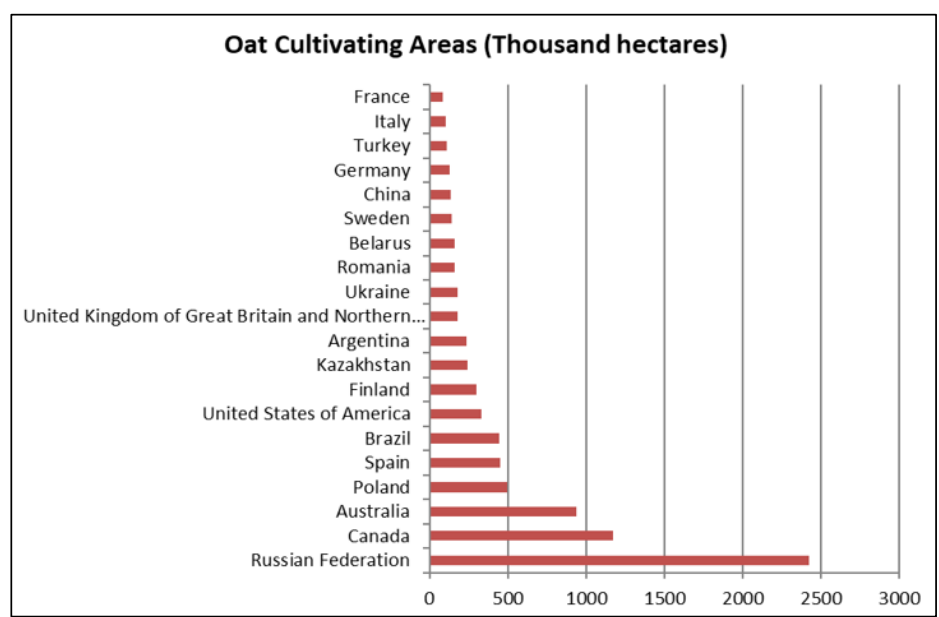

Figure 1: Oat cultivation area in the world (2019). Source: [22].

Russia is the largest producer of oats in the world and uses the majority of its production in its domestic consumption. Location of oat production in Turkey as well as in the world and the amount varies according to the nature conditions. Therefore, even if the cultivation areas do not change, the amount of production varies from year to year depending on the climate. Turkey, in terms of oats acreage, ranks 18th in the world in 2019 (FAO, 2021). According to FAO's data for 2019, the top 20 countries in terms of oat production amount in the world are given in Figure 2.

In the world, as in the cultivation areas, Russia takes first place in oat production, and the total production amount in 2019 is 4.43 million tons. According to FAO data, oat farming is carried out in 73 countries around the world in 2019, and the average oat production amount of these countries is 316.5 thousand tons. The amount of oat production in Turkey in 2019 is 265 thousand tons, $16.3 \%$ less than the world average. Turkey ranks 20th in the world of oat production by the amount of this production [22].

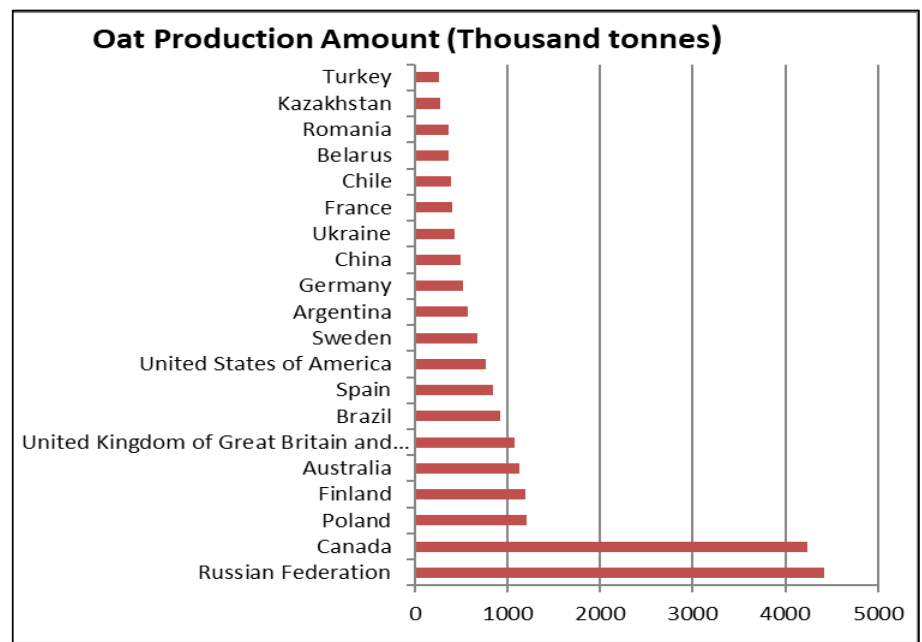

Figure 2: Oat production in the world (2019). Source: [22].

Due to the increasing world population globally, consumers tend to seek healthier and safer food and alternative products. Oat is one of the cereals whose consumption areas have diversified and become widespread recently. According to FAO data, the top 20 countries in the world in terms of oat yield are given in Figure 3.

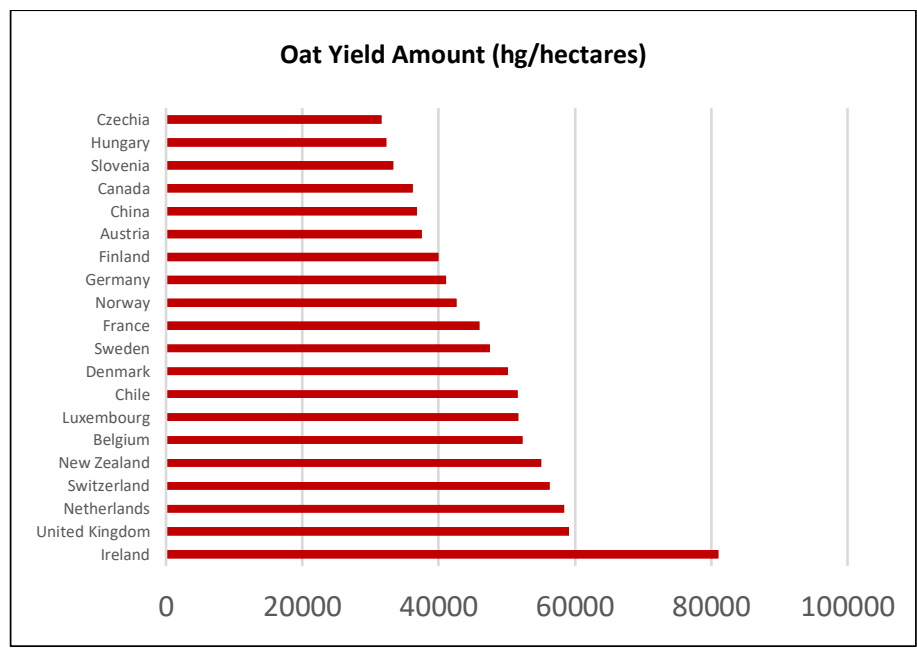

Figure 3: Oat yield in the world (2019). Source: [22].

In 2019, the average oat yield in the world is 2889 $\mathrm{kg} /$ hectare. The average yield in Turkey $2419 \mathrm{~kg} / \mathrm{hectare}$ was realized as is below $15,9 \%$ of the world average. Turkey ranks 32 in the world with this efficiency value [22]. The main purpose of this study, based on selected indicators, making an overall analysis of the oat market in Turkey in recent years and the presentation of proposals according to the results obtained.

\section{MATERIALS AND METHODS}

In the research, the statistical data of the Turkey Statistical Institute (TURKSTAT) and the United Nations Food and Agriculture Organization (FAO), and secondary data obtained from the relevant sector reports and other studies were used. For this purpose, oat production area, production amount, yield, sales 
price, import and export data between 2000 and 2019 were used. Trend analysis was conducted in the research, and projections were carried out until 2025, using data from 2000 and 2019. Trend analysis was carried out Microsoft Office program with these data. Using the data from 2000 to 2019 in the analyzes, projections were made until 2025 and the regression coefficients were determined. In addition, other studies and researches on the subject have been used in the interpretation of the results.

\section{RESULTS AND DISCUSSIONS}

To determine the trend of the oat acreage in Turkey over the years and to estimate future projections, by using the TURKSTAT data between 2000-2019 years trend analysis was carried out until 2025. The analysis result is shown in Figure 4.

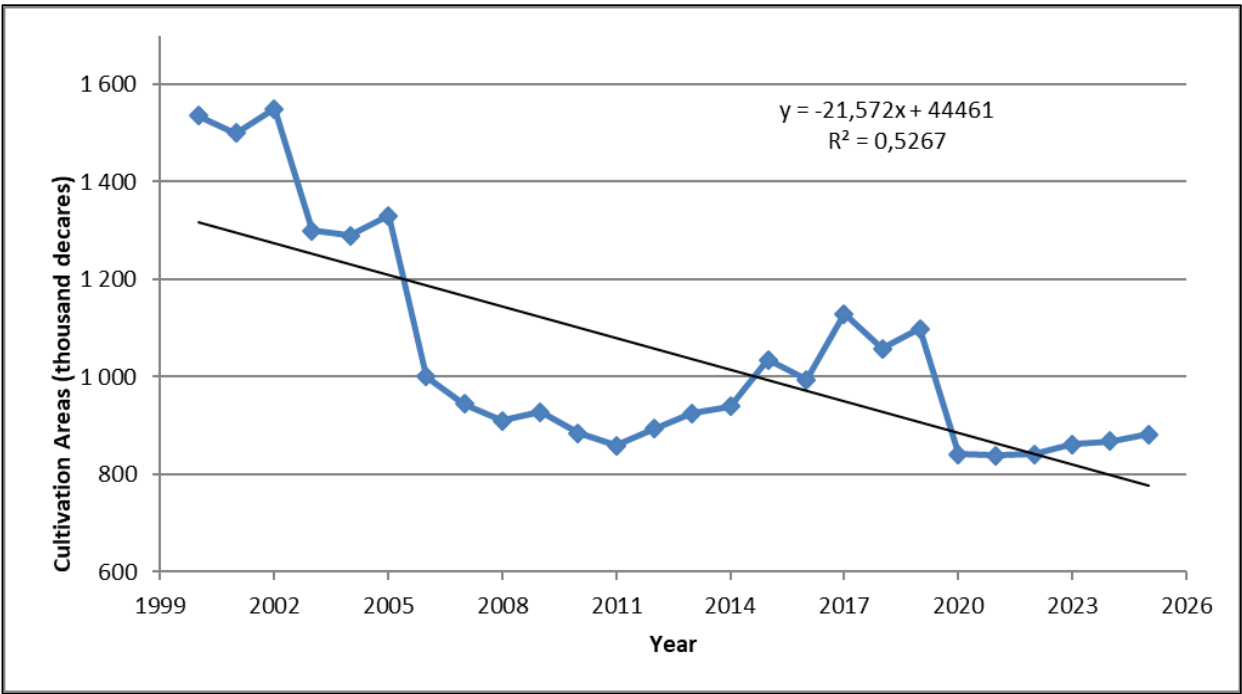

Figure 4: Oat cultivation area in Turkey (2000-2025). Source: [23].

Accordingly, cultivation areas, which were 153.6 thousand hectares in 2000, decreased to 109.82 thousand hectares in 2019. In oat acreage in Turkey, between the beginning and end of the study period, between the years 2000-2019 decline occurred of $28.5 \%$ [23]. In the projection analyses which is conducted until
2025, the oat cultivation area in Turkey as of 2020 is expected to be in the increased tendency, the regression coefficient was determined to be $52.67 \%$. The amount of oat production realized depending on the years and future projections are shown in Figure 5 .

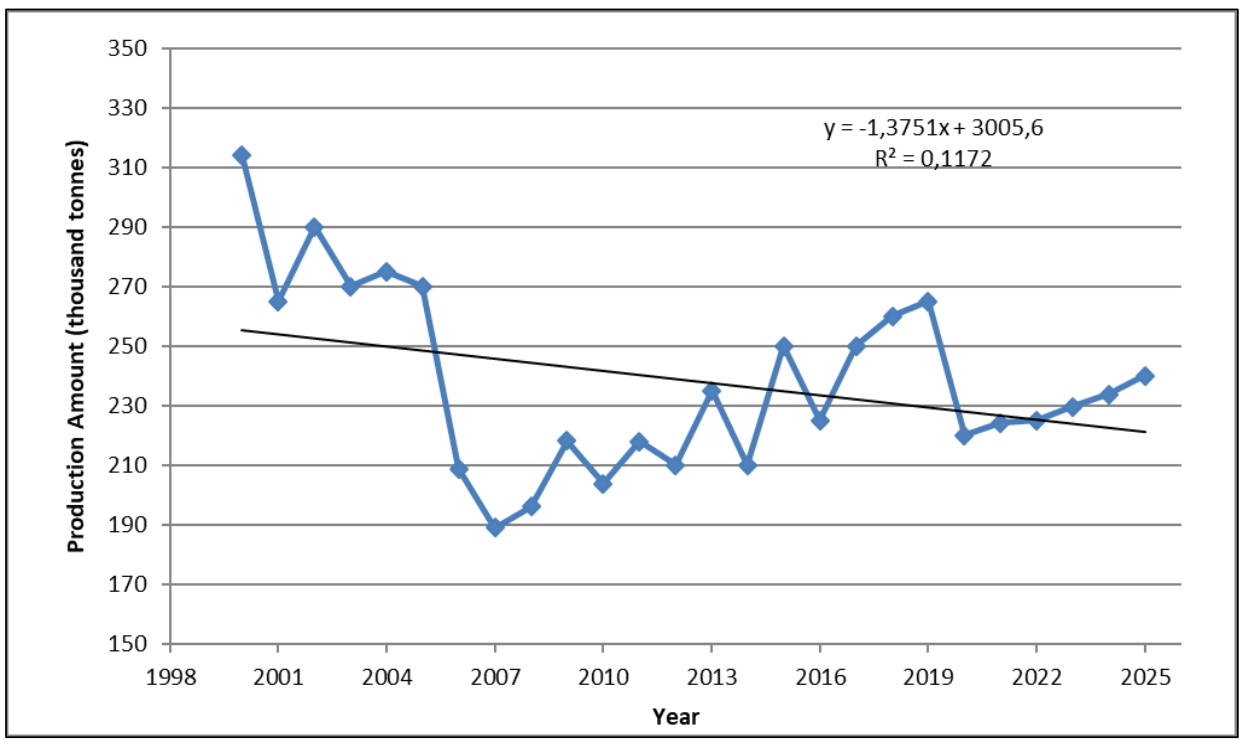

Figure 5: Oats production amount in Turkey (2000-2025).

Source: [24].

Accordingly, the production amount, which was 314 thousand tons in 2000, decreased to 265 thousand tons in 2019. The amount of oat production in Turkey between the beginning and the end of the period have decreased by $15.6 \%$ between the years 2000 to 2019 [24]. In the projection analyses which is conducted until 2025, oat production amount in Turkey as of 2020 is expected to be in the increased tendency, the regression coefficient was determined to be $11.72 \%$. To determine the trend of the oat yield in Turkey over the years and to estimate future projections, by using the TSI data between 2000-2019 years trend analysis was carried out until 2025. The oat yield change graph until 2025 is shown in Figure 6. The yield, which was $2040 \mathrm{~kg} / \mathrm{h}$ ectare in 2000, 
reached $2410 \mathrm{~kg} /$ hectare in 2019 after an increase-decrease at a fluctuating rate. Accordingly, between 2000 and 2019, oat yield increased by $18.1 \%$, and the average yield in the 20 years considered is $2200 \mathrm{~kg} /$ hectare. It is predicted that the increase in efficiency will tend to increase in the future periods, too, and the regression coefficient is $75.8 \%$. The fluctuating change in yield is explained by climatic conditions and precipitation. Because oat is a plant included in the cool climate cereals [21]. Oat yield in 2001 and 2007 in Turkey is at the lowest level. The low yield in these years was due to the precipitation in a decrease of approximately $9 \%$ compared to normal [25]. The largest increase in oat yield was 1.25 times in 2011 and 2013, and the annual average total precipitation in this period was $654.7 \mathrm{~mm}$, which was above the average of rainfall for many years [26]. Therefore, precipitation and climatic conditions are effective in yield increases and decreases. It is expected that there will be an increasing trend in the projections made for the future periods, and it should not be forgotten that the most determining factor here will be the climate.

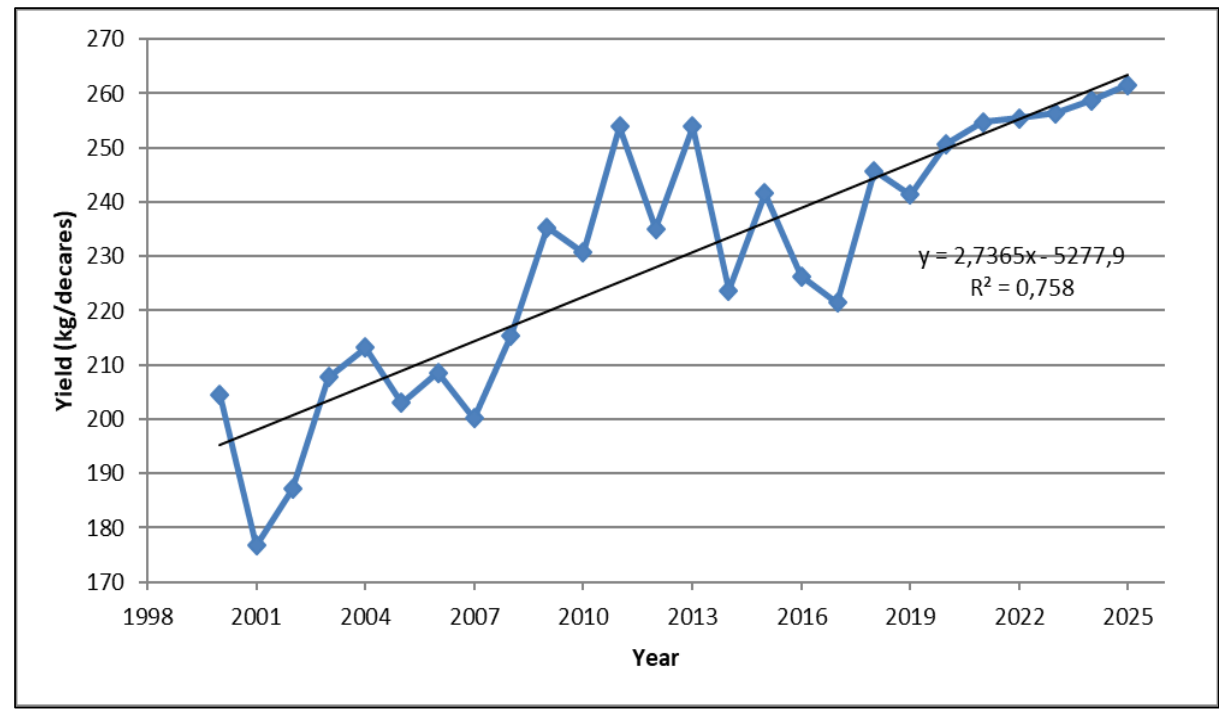

Figure 6: Oats yield in Turkey (2000-2025).

Source: [24].

To determine the trend of the oat average sales price in Turkey over the years and to estimate future projections, by using data between 2000-2019 years trend analysis was carried out until 2025. The analysis is shown in Figure 7. Sales prices increased by
14.52 times between the beginning of the period and the end of the period (between the years 2000-2019). According to the trend analysis, it is estimated that oat prices will show an increasing trend with a regression coefficient of $98.25 \%$ until 2025 .

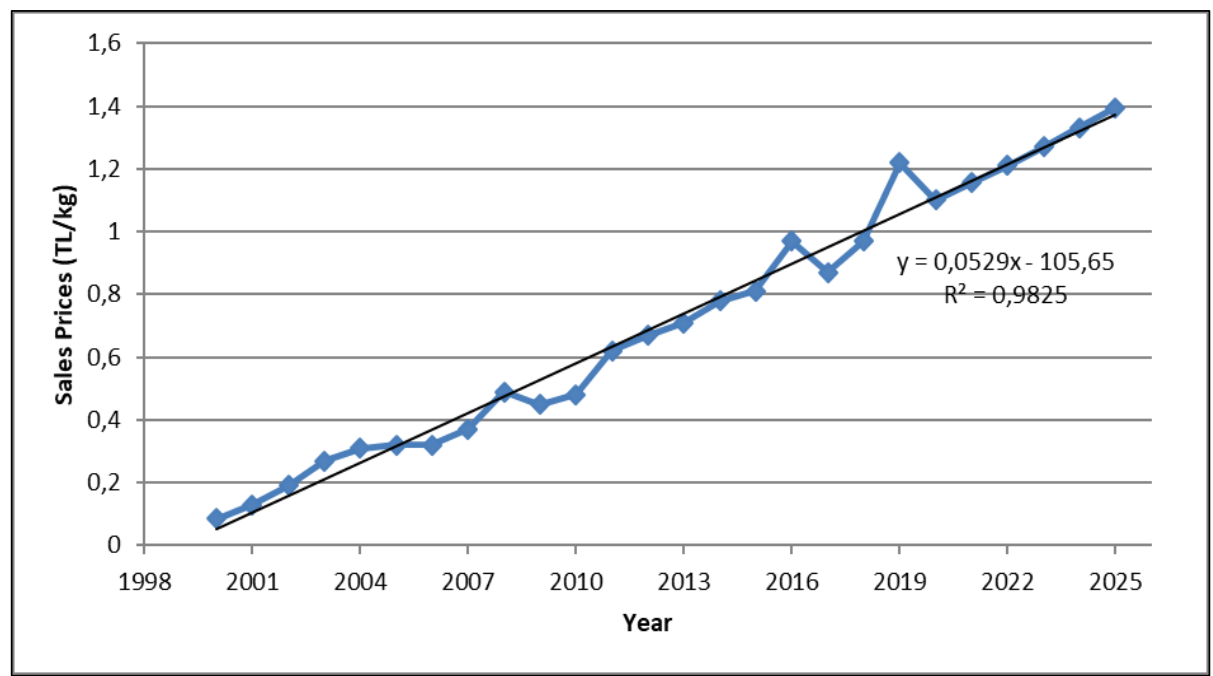

Figure 7. Oats sales price in Turkey (2000-2025).

Source: [22],[24].

Oats sales prices in Turkey between the years 2000-2019 showed a rising trend overall. Prices depend on supply and demand under general economic conditions. It is expected that prices will increase until the amount of supply meets the amount of demand. The latest data on exports and imports of oats in TURKSTAT data belong to 2018. Accordingly, trend analyzes were carried out for the period until 2025, using data between 2000 and 2018 .
Between the years 2000-2018, which is the research period, the average annual export amount was 96.42 tons. Export values fluctuated at an excessively increasing and decreasing rate depending on the years. It is interpreted that this situation arises due to the domestic consumption demand.

The graph of the trends in exports is given in figure 8 . Accordingly, exports show an increasing trend with a fluctuating course, and the regression coefficient was determined as $20.23 \%$. 


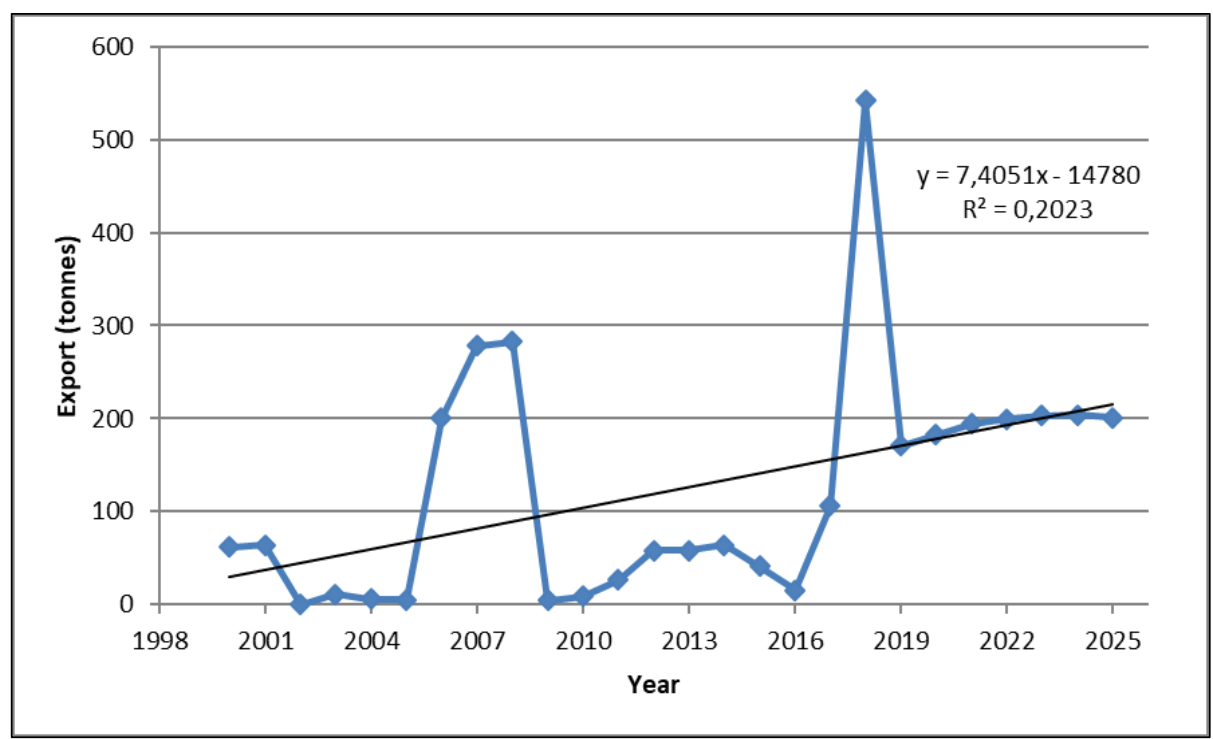

Figure 8. Turkey's oat exports (2000-2025). Source: [24].

To determine the trend of the oat import amount in Turkey over the years and to estimate future projections, by using data between 2000-2018 years trend analysis was carried out until 2025. The analysis result is shown in figure 9.

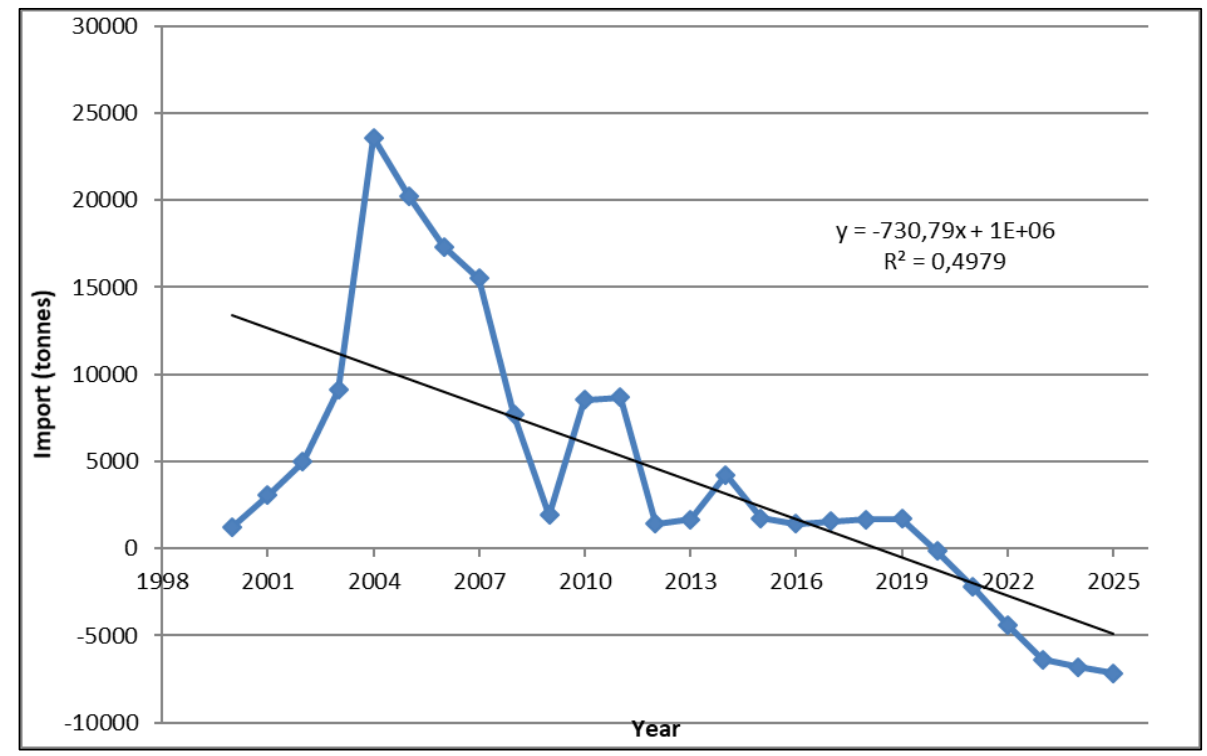

Figure 9. Turkey's oats import (2000-2025).

Source: [24].

Turkey, despite having a variable appearance of oats foreign trade, is mostly importers. Oats import; depending on the production areas and amount, use as a domestic nutrient, and the production amount of feed plants that can be substituted as raw materials to meet the developing needs of the feed industry, it varies over the years. But considering the data during the research period; increases and decreases in the amount of imports are mostly explained by cultivation areas, yield, and climate-based precipitation. The increase in the amount of imports between 20002004 is directly proportional to the increasing population and the number of animals. Import values have decreased continuously between 2004 and 2018, and it is estimated that future projections will also tend to decrease [24]. The regression coefficient of this decrease is predicted to be $49.79 \%$.

In consequence of oat processing facilities operating below the current capacity and the dry season in some production periods, oat production is at a level that cannot meet domestic consumption.
Due to the occurrence of these situations, it becomes mandatory to import oats. According to the trend analysis, oat imports are expected to decrease by 2023 . In contrast to the decrease in imports of oats in Turkey, an increase in acreage it has occurred. Oats, which are used as a nutrient in human nutrition and especially used as feed-in livestock breeding, have been produced in sufficient quantities by increasing the oat planting areas. Determination of the change in the foreign trade balance over the years in Turkey and in order to make projections for the future, export and import data were used. In terms of foreign trade, between 2000 and 2018, oat imports and exports fluctuated at increasing and decreasing rates depending on the years. As the investigated period, Turkey is a net importer until 2020, the ratio of imports shows a declining slope. As of 2020, the transition to the export trend has been detected, and it is predicted that this will continue in the coming periods. The graph of the foreign trade balance is shown in Figure 10 and the regression coefficient has been determined as $50.4 \%$. 


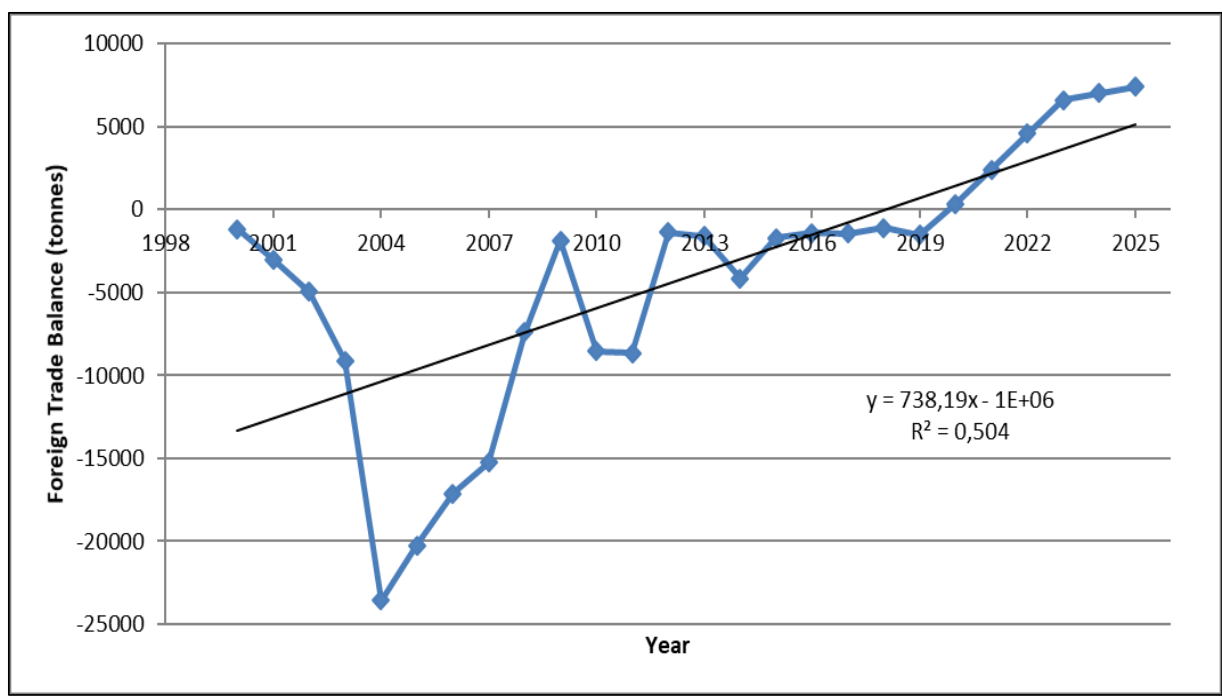

Figure 10. Turkey's foreign trade balance of oats (2000-2025).

Source: [24].

\section{CONCLUSIONS}

While Turkey among the first 18 countries in the world oat acreage, the amount of oat production is lower than it. One of the most important issue in oat cultivation is the low yield, the yield is below the world average in Turkey. In order to increase the yield, it is necessary to expand the use of technological developments, to include oats in the product pattern in irrigated agriculture, and to ensure the use of fertilizers, suitable varieties, and good seeds. Growing population in Turkey, the increase in livestock breeding, and with the development of the food industry, oat consumption has increased. Accordingly, it is necessary to increase the production level to meet domestic consumption. It is necessary to follow incentive policies and support the producers in order to expand the cultivation areas of oat, which is an alternative to many forage crops. Due to the constraints and disadvantages of rural areas, structural changes and developments in agricultural production and product pattern can be made mostly through agricultural extension activities. So much so that farmers can even show a willingness to pay for agricultural extension activities where they can earn more income [27]. Therefore, oats should be given more place in agricultural extension activities. Due to the pricing policy implemented in Turkey and the decrease in production, oats cannot compete with other products, improvement efforts are also not given adequate attention. In order for oats to be a competitive product, it needs to be supported by more public policies. This situation will also impact positively on Turkey's foreign trade. This research is important in terms of covering upto-date data on oats and future predictions. This research provides useful data for decision-makers and agricultural policymakers.

\section{AUTHOR'S CONTRIBUTION}

Conceptualization: Zeliha Şahin, Mustafa Hakkı Aydoğdu and Gönül Sevinç.

Methodology: Zeliha Şahin, Mustafa Hakkı Aydoğdu, Gönül Sevinç and Nihat Küçük.

Investigation: Zeliha Şahin and Gönül Sevinç.

Discussion of results: Zeliha Şahin and Mustafa Hakkı Aydoğdu. Writing - Original Draft: Zeliha Şahin, Mustafa Hakkı Aydoğdu, Gönül Sevinç and Nihat Küçük.

Writing - Review and Editing: Mustafa Hakkı Aydoğdu and Gönül Sevinç.
Resources: Zeliha Şahin, Mustafa Hakkı Aydoğdu, Gönül Sevinç and Nihat Küçük.

Supervision: Zeliha Şahin.

Approval of the final text: Zeliha Şahin, Mustafa Hakkı Aydoğdu, Gönül Sevinç and Nihat Küçük.

\section{REFERENCES}

[1] M. Türkeş, "Türkiye'de gözlenen ve öngörülen iklim değişikliği, kuraklık ve çölleşme," Ankara Üniversitesi Çevrebilimleri Dergisi, vol. 4, no. 2, pp. 1-32, 2012, doi: 10.1501/Csaum_0000000063.

[2] M. H. Aydogdu, "Farmers' attitudes to the pricing of natural resources for sustainability: GAP-Şanlıurfa sampling of Turkey," Water, vol. 11, no. 9, p. 1772, 2019, doi: 10.3390/w11091772.

[3] N. S. Partigöç and S. Soğanc1, "Küresel iklim değişikliğinin kaçınılmaz sonucu: Kuraklık, Resilience, vol. 3, no. 2, pp. 287-299, 2019, doi: 10.32569/resilience.619219.

[4] M. H. Aydogdu and K. Yenigün, "Farmers' risk perception towards climate change: A case of the GAP-Şanlıurfa region, Turkey," Sustainability, vol. 8, no. 8, p. 806, 2016, doi: 10.3390/su8080806.

[5] H. P. Doğan, M. H. Aydoğdu, M. R. Sevinç, and M. Cançelik, "Farmers' willingness to pay for services to ensure sustainable agricultural income in the GAPHarran Plain, Şanlıurfa, Turkey," Agriculture, vol. 10, no. 5, p. 152, 2020, doi 10.3390/agriculture10050152

[6] M. H. Aydoğdu, M. R. Sevinç, M. Cançelik, H. P. Doğan, and Z. Şahin "Determination of farmers' willingness to pay for sustainable agricultural land use in the GAP-Harran Plain of Turkey," Land, vol. 9, no. 8, p. 261, 2020, doi 10.3390/land 9080261.

[7] M. H. Aydogdu and F. Kaya, "Factors affecting consumers' consumption of organic foods: A case study in GAP-Sanliurfa in Turkey," Journal of Agricultural Science and Technology (JAST), vol. 22, no. 2, pp. 347-359, 2020.

[8] E. Yaver and N. Ertaş, "Yulafin bileşimi, hububat endüstrisinde kullanım alanları ve insan sağlığı üzerine etkileri," Glda ve Yem Bilimi Teknolojisi Dergisi, vol. 13 , pp. 41-50, 2013

[9] M. H. Aydoğdu, F. Kaya, M. E. Eren, and H. P. Doğan, "Organik ürün tüketim nedenleri üzerine bir arastırma: Sanlıurfa örneklemesi," Asos Journal, vol. 6, no. 64, pp. 161-170, 2018, doi: 10.16992/ASOS.12764.

[10] M. H. Aydoğdu, F. Kaya, G. Sevinç, and N. Küçük, "Organik tarımın önemi ve geleceği üzerine bir değerlendirme," TURAN-SAM, Turan Stratejik Arassttrmalar Merkezi, vol. 11, no. 42, pp. 264-270, 2019, doi: 10.15189/1308-8041.

[11] İ. Naneli and M. A. Sakin, "Bazı yulaf cesitlerinin (Avena sativa L.) farkl lokasyonlarda verim ve kalite parametrelerinin belirlenmesi," Tarla Bitkileri 
Merkez Araştırma Enstitüsü Dergisi, vol. 26, pp. 37-44, 2017, doi: 10.21566/tarbitderg.359057.

[12] R. Karaman, İ. Akgün, and C. Türkay, "İnsan beslenmesinde alternatif besin kaynağı: Yulaf,” Türk Bilim ve Mühendislik Dergisi, vol. 2, no. 2, pp. 78-85, 2020.

[13] M. Çalışkan, A. Koç, F. A. Vuran, F. Yüceol, and Ç. Sayılgan, "Batı Akdeniz Bölgesi yerel yulaflarının bazı tarımsal ve kalite özellikleri yönünden değerlendirilmesi," ANADOLU Ege Tarımsal Araştırma Enstitüsü Dergisi, vol. 30, no. 2, pp. 179-196, 2020, doi: 10.18615/anadolu.834905.

[14] Z. Dumlupınar, A. Tekin, S. Herek, A. Tanrıkulu, T. Dokuyucu, and A. Akkaya, "Evaluating some Turkish originated oat genotypes for some agronomic traits," Turkish Journal of Agriculture - Food Science and Technology, vol. 5, no. 7, pp. 763-772, 2017, doi: 10.24925/turjaf.v5i7.763-772.1181.

[15] Turkey Seed Growers Association, "Yulaf Üretimi ve Yetiştiriciliği!!," 2012. https://turktob.org.tr/tr/yulaf-uretimi-ve-yetistiriciligi/4910 (accessed Mar. 09, 2021).

[16] N. Sarı, "Yulafta (Avena sativa L.) verim ve verim komponentleri arasındaki ilişkiler," Master's thesis, Adnan Menderes University, Aydın/Turkey, 2012.

[17] M. Ayub, M. Shehzad, M. A. Nadeem, M. Pervez, M. Naeem, and M. Sarwar, "Comparative study on forage yield and quality of different oat (Avena sativa L.) varieties under agro-ecological conditions of Faisalabad, Pakistan," African Journal Agriculture Research, vol. 6, pp. 3381-3391, 2011.

[18] A. Khan, M. H. Anjum, M. K. U. Rehman, Q. uz Zaman, and R. Ullah, "Comparative study on quantitative and qualitative characters of different oat (Avena sativa L.) genotypes under agro-climatic conditions of Sargodha, Pakistan," American Journal of Plant Sciences, vol. 5, no. 20, pp. 3097-3103, 2014, doi: 10.4236/ajps.2014.520326.

[19] National Grain Council, "Grain Report," 2016. http://uhk.org.tr/dosyalar/uhkarpa_kasim2015.pdf (accessed Mar. 09, 2021).

[20] N. Sarı, A. İmamoğlu, and Ö. Yıldız, "Menemen ekolojik koșullarında bazı ümitvar yulaf hatlarının verim ve kalite özellikleri," ANADOLU Ege Tarımsal Araştırma Enstitüsü Dergisi, vol. 22, no. 1, pp. 18-32, 2012.

[21] Republic of Turkey Ministry of Agriculture and Forestry, "Agricultural supports," 2021. https:/www.tarimorman.gov.tr/Konular/TarimsalDestekler/Alan-Bazli-Destekler/Mazot-Gubde-ve-Toprak-Analizi-

Destegi?Ziyaretci=Ciftci.

[22] FAO, "Crops, oats, area harvested, yield, production," 2021. http://www.fao.org/faostat/en/\#data (accessed Feb. 15, 2021).

[23] TURKSTAT, "Agricultural Area," 2021. https://biruni.tuik.gov.tr/medas/?kn=92\&locale=tr (accessed Mar. 10, 2021).

[24] TURKSTAT, "Cereals and Other Crop Products," 2021. https://biruni.tuik.gov.tr/medas/?kn=92\&locale=tr (accessed Mar. 10, 2021).

[25] Republic of Turkey Ministry of Agriculture and Forestry, "Evaluation of 2009 Climate Data," 2010. https://www.mgm.gov.tr/FILES/iklim/2009-yili-iklimdegerlendirmesi.pdf (accessed Feb. 11, 2021).

[26] Republic of Turkey Ministry of Agriculture and Forestry, "Climate Assessment for 2012," 2013. https:/www.mgm.gov.tr/FILES/iklim/2012-yili-iklimdegerlendirmesi.pdf (accessed Feb. 10, 2021).

[27] M. H. Aydogdu, "Evaluation of farmers' willingness to pay for agricultural extension services in GAP-Harran Plain, Turkey," Journal of Agricultural Science and Technology (JAST), vol. 19, no. 5, pp. 785-796, 2017. 